\title{
Water quality impacts of small-scale hydromodification in an urban stream in Connecticut, USA
}

Bin Zhu ${ }^{1 *}$ D, Daniel S. Smith ${ }^{1}$, Anthony P. Benaquista ${ }^{1}$, Dylan M. Rossi ${ }^{1}$, Betsy M. Kadapuram ${ }^{1}$, Man Lok Yu², Andrew S. Partlow ${ }^{1}$ and Nathan R. Burtch ${ }^{3}$

\begin{abstract}
Introduction: Construction activities in and along urban streams increase the sediment input into surface waters, causing an overall decline in water quality and aquatic ecosystems. In this case study, we investigate the water quality impacts of local hydromodification in an urban stream (discharge $0.4 \mathrm{~m}^{3} / \mathrm{s}$ ). At the site of interest, workers removed a stream crossing consisting of an embankment with culverts and replaced it with a small bridge (single span of $25 \mathrm{~m}$ ) in an effort to improve flow capacity.

Methods: Water samples were taken at four sites along the North Branch Park River in Connecticut, Northeastern United States. Turbidity and dissolved oxygen (DO) were measured in situ, and nitrate and total phosphorus (TP) were measured in the laboratory. Benthic macroinvertebrate samples were also collected and analyzed for taxon richness and Shannon-Weaver species diversity. Data were compared between upstream and downstream sites and before, during, and after hydromodification. We used one-way ANOVA combined with the post hoc Turkey test to derive statistical significance.

Results: During construction, turbidity increased temporarily by $60.9 \%$ [from 2.48 Nephelometric Turbidity Units (NTU) over ambient to $4.00 \mathrm{NTU}$. Once construction was completed, DO increased locally from 11.0 to $13.0 \mathrm{mg} / \mathrm{L}$. Benthic macroinvertebrate taxon richness and species diversity declined by 61.6 and $32.6 \%$ respectively, with no recovery observed in the year following construction. Water quality was only affected within $50 \mathrm{~m}$ downstream. Nitrate and TP concentrations were unaffected.

Conclusions: Small-scale hydromodification temporarily increased the turbidity as a result of increased sediment input, approaching the maximum level for clean water (5 NTU). Benthic macroinvertebrate communities declined in the immediate downstream vicinity of construction but are expected to recover soon given that turbidity recovered to pre-construction levels, and DO increased. These outcomes emphasize that environmental assessment is important not only for large-scale hydromodification but also for smaller scale stream modifications.
\end{abstract}

Keywords: Urban streams, Pollution, Hydrologic services, Water quality, Benthic macroinvertebrates, North Branch Park River

\footnotetext{
* Correspondence: zhu@hartford.edu

'Department of Biology, University of Hartford, 200 Bloomfield Avenue, West

Hartford, CT 06117, USA

Full list of author information is available at the end of the article
} 


\section{Introduction}

Construction activities and hydromodification are recognized as major sources of water quality impairment in urban streams, because they increase sediment input into waterways and downstream aquatic ecosystems (Brabec et al. 2002; Meyer et al. 2005; Chen et al. 2009; Houser and Pruess 2009; Hassan et al. 2015). Highway construction can lead to a rapid decline in stream water quality (e.g., suspended solids, iron, chloride, sulfate, nitrogen, and $\mathrm{pH}$ ), not only during construction but also in the period that follows (Chen et al. 2009; Purcell et al. 2012). The pollution from this type of large construction projects degrades aquatic ecosystems and has severe impacts on food webs (Bennett et al. 2001). Evidence suggests that aquatic ecosystems in small streams are equally susceptible to pollution by sediment (Lemly 1982); however, the local water quality impacts in these small streams are extremely variable (Berger et al. 2017).

A healthy aquatic ecosystem depends on minimum standards for water quality, defined to guarantee sufficient dissolved oxygen (DO) concentrations $(>5 \mathrm{mg} / \mathrm{L}$ ) and limited phosphorus and nitrogen concentrations (Bennett et al. 2001; Le et al. 2010). Reduced water quality is often first visible in higher turbidity caused by light scattering coming from particles present in the water column. Turbidity increases the temperature of water, which can then hold less oxygen. Oxygen is further reduced when eutrophication resulting from excess phosphorus and nitrogen input causes an algal bloom that consumes the oxygen (Correll 1998; Patil and Deng 2012; Hobbie et al. 2017). The effects of water quality impairment on food chains, including benthic macroinvertebrate and fish communities, are often immediate and profound (DaSilva et al. 2013; Hassan et al. 2015). Fish experience physiological effects from high sediment loads, affecting reproductive behavior (Bilotta and Brazier 2008). The decline of benthic macroinvertebrate communities affects recreational fishing and aquaculture, decimating the local value of these ecosystem services (Patil and Deng 2012). Benthic macroinvertebrates have specific requirements for DO, nutrients, and light penetration (Covich et al. 1999; Mundahl and Hunt 2011). This explains why they are an important proxy for water quality and ecosystem health (e.g., Quinn et al. 1997; Weigel et al. 2002; Chen et al. 2009; Mundahl and Hunt 2011).

Increased concern for what is collectively known as the urban stream syndrome, attributed to urban infrastructure, has paved the way for a shift in how urban streams are valuated in the USA. More emphasis is now placed on optimizing the balance between on the one hand efficient storm drainage-an important market ecosystem service-and on the other hand biodiversity, support for urban ecosystems, habitat for plant and animal life, and social services (esthetic and recreational), which are critical nonmarket ecosystem services (Wilson and Carpenter 1999; Sun et al. 2017). Frequent flooding disrupts this balance, as is the case for the North Branch Park River in Connecticut, Northeastern United States. In there, a combination of increased paved surface and sewer overflows in the upstream watershed carries excess sediment and adsorbed pollutants into the stream (Fuss and O'Neill 2010). Flooding and water quality impairment have prompted a local shift to low impact development and river restoration in the watershed (Fuss and O'Neill 2010). Nonetheless, impacts on sediments, nutrients, oxygen, and biotic assemblages are difficult to predict due to the complexity of urban hydrologic systems (Meyer et al. 2005).

The objective of this study was to evaluate the water quality impacts of flow improvement works in the urban North Branch Park River (drainage area $74.1 \mathrm{~km}^{2}$ ) in Connecticut, Northeastern United States. In the studied location, a stream crossing in the form of an embankment with culverts was replaced with small single-span bridge to increase flow capacity and reduce flood occurrence in the immediate upstream vicinity. We evaluated the impacts of this flow improvement project on water quality by comparing turbidity [a common indicator of suspended solids], dissolved oxygen (DO), total phosphorus (TP), and benthic macroinvertebrate abundance, taxon richness and diversity (Weigel et al. 2002; Chen et al. 2009; Hassan et al. 2015) measured before, during, and after construction.

\section{Methods}

\section{North Branch Park River}

The North Branch Park River in Connecticut, Northeastern United States, drains a $74.1-\mathrm{km}^{2}$ urban watershed that includes part of the city of Hartford and adjacent communities. This watershed is part of the Connecticut River basin (Fig. 1a) and home to approximately 48,000 residents (Fuss and O'Neill 2010). Temperatures exceeded $32.2{ }^{\circ} \mathrm{C}$ during 19 days/year on average, and descended below $-17.8{ }^{\circ} \mathrm{C}$ during 6 days/year (Fuss and O’Neill 2010). With a precipitation of $1172 \mathrm{~mm} /$ year and snowfall of $1151 \mathrm{~mm} /$ year between 1971 and 2000 (at Bradley International Airport, National Climatic Data Center), climate is characterized as hot-summer humid continental (Dfa).

The studied section of the North Branch Park River runs through the middle of the University of Hartford campus. Median discharge was $0.43 \mathrm{~m}^{3} / \mathrm{s}$ (2015-2017 data for gauging station 1,191,000, US Geological Survey in cooperation with the City of Hartford), and flow velocity varied between 0.3 and $3.0 \mathrm{~m} / \mathrm{s}$ (Fuss and O'Neill 2010).

\section{Hydromodification}

There are three stream crossings along the studied stream section, including (along the direction of flow; 

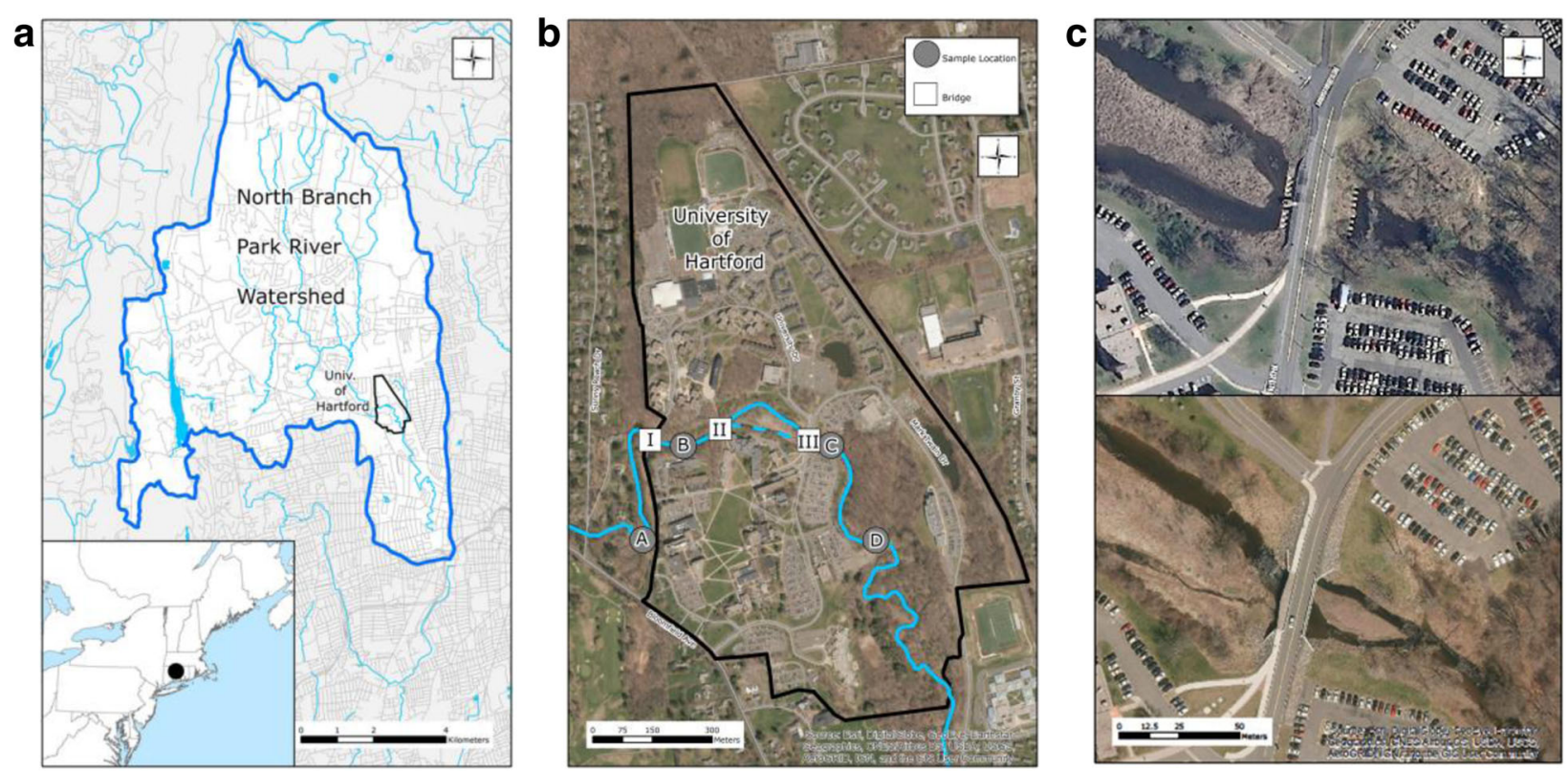

Fig. 1 a Location of the North Branch Park River watershed in Connecticut, USA. b Location of the four sampling sites. Sites A and B were located upstream of the construction site, and sites $C$ and D were downstream of the construction site. Stream crossing I is a concrete single-span road bridge, stream crossing II is a pedestrian truss bridge, and stream crossing III is the new concrete single-span road bridge. The dashed line represents a stream channel that only conducts water during high flow; only the northern channel conducts water during normal flow. c Satellite view of the previous structure (embankment with culverts) in March 2012 (top) and the new structure (bridge) after it was completed in February 2013 (bottom)

Fig. 1b) a road bridge (I) and a pedestrian bridge (II), and another road bridge (III). The upstream single-span concrete bridge (I) and pedestrian truss bridge (II) have sufficiently wide spans to allow flow to pass unimpeded -27 and $72 \mathrm{~m}$, respectively, the latter supported by a pier along the stream bank. The site of interest was the third stream crossing (III) $\left(41.7986^{\circ} \mathrm{N}, 72.7132^{\circ} \mathrm{W}\right)$. A bridge with a single span of $25 \mathrm{~m}$ was built at this location, to replace a stream crossing in the form of an embankment with culverts that severely impeded throughput of high water flows (Fig. 1c).

The former structure supported a paved road and allowed water to pass through eight culverts, each $76.2 \mathrm{~cm}$ in diameter and $21 \mathrm{~m}$ long, with two culverts submerged during normal flow. The combined flow capacity of these culverts was insufficient during fullbank discharge-the average channel width at this location is approximately $12 \mathrm{~m}$, with a bankfull width of $75 \mathrm{~m}$-and frequently caused water to back up behind the embankment. This resulted in repeated flooding of the adjacent parking lots, and a solution was urgently needed.

The site was modified in an effort to increase flow capacity and reduce flood risk in the direct upstream vicinity. First, the stream was temporarily diverted, and the embankment demolished. Next, the construction of a single-span bridge started in the same location. Concrete foundations were laid, and abutments were created on top. The superstructure was suspended and secured in place, and the deck was paved with asphalt to create the road. Finally, the stream was rerouted to its original pathway. The building project started in June 2012, and the bridge was completed in February 2013. The 25-m span of the bridge substantially increased the flow capacity. No new occurrences of flooding were reported after this.

\section{Water sampling}

Four sampling sites were selected along a 1200-m reach that comprises all three stream crossings (Fig. 1b). In the direction of flow, site A was the furthest upstream sampling site, followed by stream crossing I, then site B, stream crossing II, and stream crossing III, where construction took place. Site A and site B were located 680 and $260 \mathrm{~m}$ upstream of the construction site, respectively, and site $C$ and site D were located 50 and $365 \mathrm{~m}$ downstream of the construction site, respectively. Discharge was comparable along this stream section, with no tributaries, and the channel and stream bank characteristics in these sites were as follows:

Site A: Rocky streambed, gentle bank slope, bank vegetation largely absent

Site B: Gravel streambed, gentle bank slope, open bank vegetation

Site C: Sandy streambed, gentle bank slope, open bank vegetation 
Site D: Sandy streambed, steep bank slope, open bank vegetation with plant debris

Water samples were collected on a monthly basis over the course of three 6-month periods, each of which included the fall and winter seasons: prior to construction work during the period between September 2011 and February 2012, during construction from September 2012 to February 2013, and after construction from September 2013 to February 2014. The sampling periods were selected based on the construction period and accessibility of sampling sites. No samples were collected at site D in February 2014 when the stream was frozen. To obtain baseline data, samples were collected on nonrainy days at least 5 days after a storm event or intense snowmelt. Triplicate samples were collected on each site and at each sampling date directly below the water surface in the center of the stream channel (standard protocol, US Geological Survey National Water-Quality Assessment Project) (number of samples $n=204$ ).

\section{Turbidity, DO, nitrate, and total phosphorus determination}

During water sampling, turbidity was measured in situ with the 2100Q Portable Turbidimeter (Hach Company, Loveland, Colorado), and DO was measured with the Orion 4 Star pH/DO Portable Meter (Thermo Scientific, Madison, Wisconsin). In the laboratory, water samples were prepared for nitrate determination using the cadmium reduction method and samples for TP analysis were prepared using the acid persulfate digestion method. Nitrate and TP concentrations were determined by using the Genesys 10s UV-Vis spectrophotometer (Thermo Scientific, Madison, WI) following the EPAapproved standard procedures (Eaton and Franson 2005).

\section{Benthic macroinvertebrate sampling and analysis}

Benthic macroinvertebrates were also collected on a monthly basis during the same three 6-month periods. A Turtox D-Shaped dip net $(45 \times 23 \mathrm{~cm}$, Wildco, Buffalo, New York) was dragged across the streambed over a length of $15 \mathrm{~m}$ between the left and right banks, while stirring up the streambed sediment with feet. The materials collected in the net were placed in a $250-\mu \mathrm{m}$ sieve (Will Scientific Inc., Rochester, New York), rinsed several times, and then transferred to a collection bottle for further analysis. Three samples were collected at each site. Again, no samples were collected at site D in February 2014 when the stream was frozen.

In the laboratory, benthic macroinvertebrates were identified using the keys provided by Thorp and Covich (2009). After classifying the organisms, specimens were preserved in $95 \%$ ethanol. Taxon abundance was estimated as the mean number of specimens per taxon divided by the surveyed area. The taxon richness (number of unique taxa) and Shannon-Weaver index of taxonomic diversity were also calculated (Zhu et al. 2006; Mundahl and Hunt 2011; Zhu et al. 2015).

\section{Statistical analysis}

Prior to statistical analysis, water quality data were transformed to reduce heteroscedasticity by taking the natural logarithm $[\ln (x+1)]$. One-way analysis of variance (ANOVA) was performed to test the equality of means for individual water quality indicators (turbidity, nitrate, TP, and benthic macroinvertebrate taxon richness and species diversity) between sampling sites (A, B, C, and D) (Kuehl 2000). This was done for the periods prior to construction, during construction, and after construction, respectively. A second ANOVA was performed to test the equality of the same means between these periods for each sampling site. In other words, the first ANOVA evaluates along-stream differences in water quality for each period, and the second ANOVA identifies time-dependent changes at individual sampling sites.

Because ANOVA only indicates whether or not the evaluated means are presumed equal, the post hoc Tukey test was performed to compare all possible pairs of means and precisely identify the differences that are greater than the standard error (SE) (Kuehl 2000). All statistical analyses were conducted using IBM SPSS Statistics 21 (IBM Corporation, Armonk, New York). Statistical significance was determined for $\alpha=0.05$.

\section{Results}

Turbidity

No difference in turbidity was observed between sites prior to construction ( $\mathrm{df}=3, F=0.13, p=0.944$ ) or after construction ( $\mathrm{df}=3, F=1.45, p=0.238)$. But, during the construction period, a significant difference started to develop ( $\mathrm{df}=3, F=4.05, p=0.010$; Table 1 and Fig. 2), when turbidity increased immediately downstream of the construction site during construction period and returned to prior levels after construction. This is reflected by measurements for site C (Fig. 2), where values first increased from $2.48 \pm 0.36$ Nephelometric Turbidity Unit (NTU) to $4.00 \pm 0.94 \mathrm{NTU}(+60.9 \%)$ and then decreased to $2.4 \pm 0.15 \mathrm{NTU}$ ( $\mathrm{df}=2, F=46.9, p<0.001)$.

A similar but less extreme pattern was observed further downstream of construction at site $\mathrm{D}$, where turbidity increased from $2.55 \pm 0.32 \mathrm{NTU}$ to $3.32 \pm 0.36 \mathrm{NTU}$ during construction and then decreased to $2.64 \pm$ 0.18 NTU ( $\mathrm{df}=2, F=12.4, p<0.001)$. By contrast, turbidity did not change significantly at upstream site A ( $\mathrm{df}$ $=2, F=0.62, F=0.542$ ) whereas turbidity at site $\mathrm{B}$ decreased slightly from $2.23 \pm 0.23$ NTU to $1.82 \pm$ 
Table 1 Results of one-way ANOVA

\begin{tabular}{|c|c|c|c|c|c|c|c|c|}
\hline \multirow[t]{2}{*}{ Water quality indicator } & & \multicolumn{3}{|c|}{ ANOVA between sampling sites } & \multicolumn{4}{|c|}{ ANOVA between periods } \\
\hline & & Before construction & During construction & After construction & Site A & Site B & Site C & Site D \\
\hline \multirow[t]{2}{*}{ Turbidity } & $F$ & 0.127 & 4.051 & 1.445 & 0.623 & 6.346 & 46.927 & 12.429 \\
\hline & $p$ value & 0.944 & 0.010 & 0.238 & 0.542 & 0.004 & $<0.001$ & $<0.001$ \\
\hline \multirow[t]{2}{*}{ DO } & F & 0.105 & 0.149 & 0.118 & 2.881 & 1.588 & 5.552 & 2.896 \\
\hline & $p$ value & 0.956 & 0.929 & 0.948 & 0.090 & 0.239 & 0.017 & 0.091 \\
\hline \multirow[t]{2}{*}{ Nitrate } & F & 1.138 & 0.479 & 0.044 & 47.000 & 59.305 & 48.666 & 44.006 \\
\hline & $p$ value & 0.340 & 0.698 & 0.988 & $<0.001$ & $<0.001$ & $<0.001$ & $<0.001$ \\
\hline \multirow[t]{2}{*}{$\mathrm{TP}$} & F & 0.067 & 0.410 & 0.502 & 14.038 & 142.671 & 26.721 & 61.170 \\
\hline & $p$ value & 0.977 & 0.746 & 0.682 & $<0.001$ & $<0.001$ & $<0.001$ & $<0.001$ \\
\hline \multirow[t]{2}{*}{ Macroinvertebrate taxon richness } & F & 17.459 & 5.687 & 1.113 & 2.442 & 5.000 & 46.731 & 2.016 \\
\hline & $p$ value & $<0.001$ & 0.006 & 0.370 & 0.121 & 0.022 & $<0.001$ & 0.173 \\
\hline \multirow{2}{*}{$\begin{array}{l}\text { Shannon-Weaver macroinvertebrate } \\
\text { species diversity }\end{array}$} & F & 5.705 & 1.711 & 2.189 & 3.782 & 3.029 & 5.239 & 0.500 \\
\hline & $p$ value & 0.005 & 0.197 & 0.125 & 0.049 & 0.081 & 0.020 & 0.618 \\
\hline
\end{tabular}

Left: Comparison of sampling site means of turbidity, DO, nitrate, TP, macroinvertebrate taxon richness, and Shannon-Weaver macroinvertebrate species diversity, evaluated for the periods before (BE), during (DU), and after construction (AF). Right: Comparison of periodic means (BE, DU, AF) of the same variables per sampling site

0.22 NTU during construction and then declined again to $2.30 \pm 0.15 \mathrm{NTU}(\mathrm{df}=2, F=6.35, p=0.004$; Table 1$)$.

\section{DO, nitrate, and total phosphorus}

DO concentrations increased significantly at site $\mathrm{C}$ after construction $(\mathrm{df}=2, F=5.55, p=0.017$; Table 1$)$, from less than 11.0 to $13.0 \mathrm{mg} / \mathrm{L}$ (Fig. 3a). Modest increases were also observed at the other sites, but these increases were not significant $(p>0.05)$, and similar across the sites before, during, and after construction (Fig. 3a; all $p>0.05)$. DO concentrations were highest during the colder months (maximum of $16.4 \mathrm{mg} / \mathrm{L}$ measured in January 2014) and lowest during the warmer months (5.70 mg/L in September 2011).

Although there were significant temporal differences in nitrate and TP concentrations (Fig. 3b, c), values were always similar for the four sampling sites (all $p>0.05$;
Table 1). Nitrate concentrations were highest before construction $(0.38 \mathrm{mg} / \mathrm{L})$, declined during construction, and finally increased again after construction to a value below the pre-construction reading $(0.34 \mathrm{mg} / \mathrm{L})$ (Fig. $3 \mathrm{~b})$. TP was also similar across sampling site and decreased markedly throughout the observed period, from a value of approximately $50 \mu \mathrm{g} / \mathrm{L}$ before construction, to $35 \mu \mathrm{g} /$ $\mathrm{L}$ and $25 \mu \mathrm{g} / \mathrm{L}$ during and after construction, respectively (Fig. 3c).

\section{Benthic macroinvertebrate abundance, taxon richness, and diversity}

Benthic macroinvertebrate taxon richness and species diversity showed the greatest change directly downstream of the construction site $(p<0.02$ for site C; Table 1) and became more similar across the four sampling sites after construction was complete $(p>0.05)$.

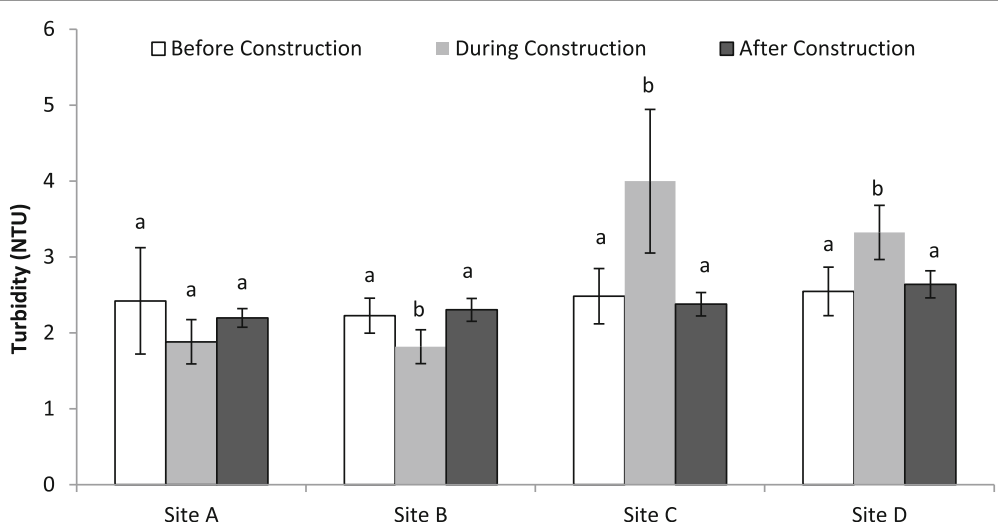

Fig. 2 Turbidity at the four sampling sites in the North Branch Park River. Bars indicate the mean \pm 1 standard error (SE). The (a, b) markings above the columns indicate the groups identified with the Tukey test $(a=0.05)$ 

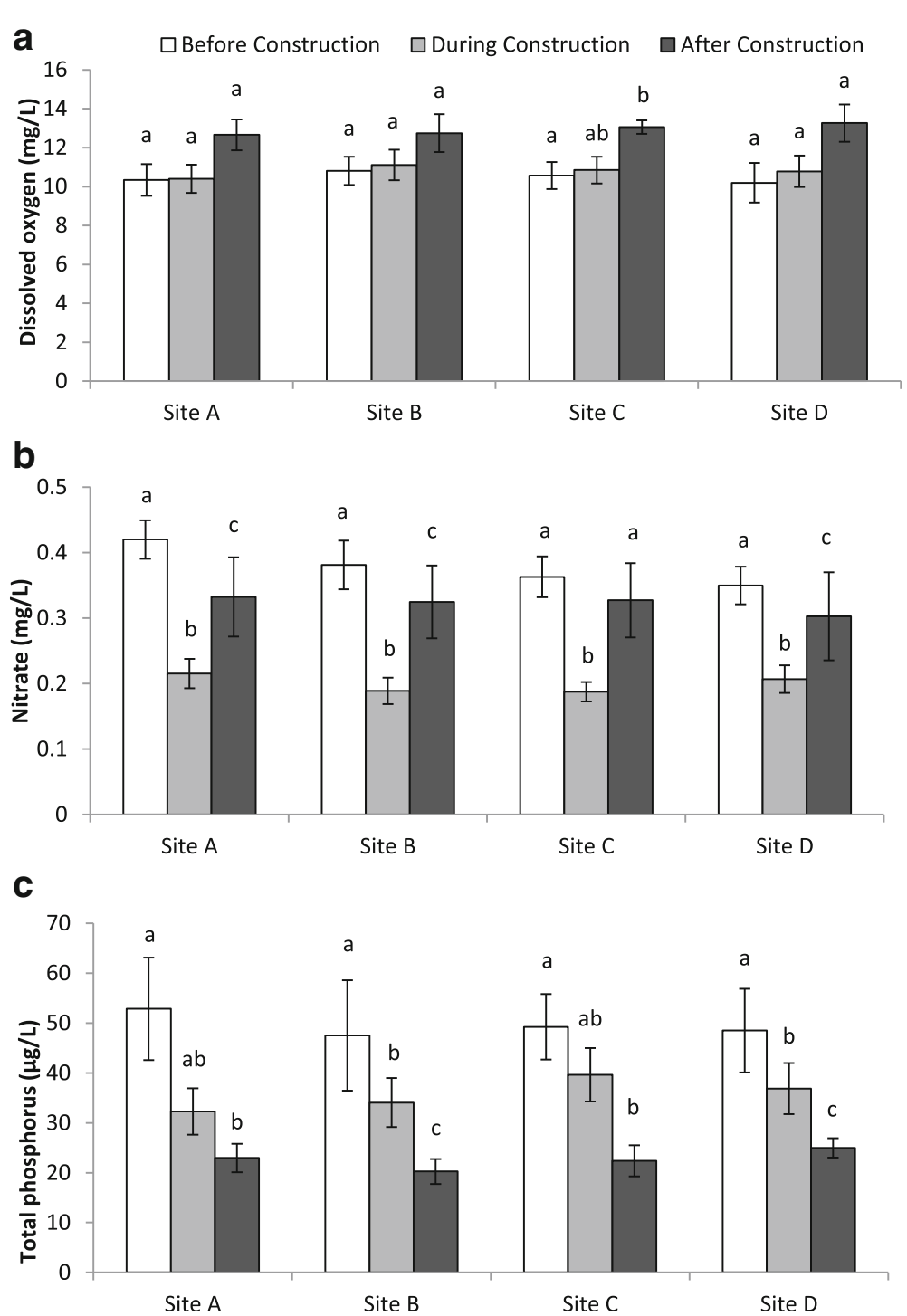

Fig. 3 Dissolved oxygen (a), nitrate concentration (b), and total phosphorus concentration (c) at the four sampling sites in the North Branch Park River. Bars indicate the mean \pm 1 SE. The $(a, b)$ markings above the columns indicate the groups identified with the Tukey test $(a=0.05)$

Before construction, the most abundant organism at all sampling sites was the aquatic worm, ranging from 6.5 individuals $/ \mathrm{m}^{2}$ at site A to 13.8 individuals $/ \mathrm{m}^{2}$ at site $\mathrm{C}$ (Table 2). The second most abundant organism at all sites was the Mayfly larva, with between 1.9 and 8.0 individuals $/ \mathrm{m}^{2}$. Midge was also found at all sites.

Before construction, abundance at downstream site $\mathrm{C}$ and site D was greater than at upstream site A and site B. But numbers declined drastically during construction. For example, the number of aquatic worms decreased from 13.8 individuals $/ \mathrm{m}^{2}$ before construction to 0.7 individuals $/ \mathrm{m}^{2}$ during construction and 0.9 individuals $/ \mathrm{m}^{2}$ after construction. In contrast, horsehair worm and mayfly larva populations increased during and after construction at downstream site $\mathrm{C}$ and site D. Caddisfly larvae were observed at site $\mathrm{C}$ and site $\mathrm{D}$ before and after, but not during construction. Other taxa including planarian, soldier fly larva, and stonefly larva seem to have disappeared altogether after construction.

Taxon richness also differed significantly between the four sites before construction $(\mathrm{df}=3, F=17.46, p<$ 0.001; Table 1 and Fig. 4a, b). During construction, taxon richness was lowest at site $C$ whereas site $B$ had the highest richness $(\mathrm{df}=3, F=5.69, p=0.006)$. Taxon richness did not change significantly at site $\mathrm{A}(\mathrm{df}=2, F=$ 2.44, $p=0.121)$ and site $\mathrm{D}(\mathrm{df}=2, F=2.02, p=0.173)$, but decreased slightly at site $\mathrm{B}$ after construction $(\mathrm{df}=2$, $F=5.00, p=0.022$ ). An even more substantial decrease was observed at site $C$, where taxon richness declined from $7.3 \pm 0.4$ before construction to $2.8 \pm 0.7$ during 
Table 2 Composition and mean abundance (individuals $/ \mathrm{m}^{2}$ ) of benthic macroinvertebrates at the four sampling sites during the periods before (BE), during (DU), and after construction (AF). Missing values indicate that no specimens were identified

\begin{tabular}{|c|c|c|c|c|c|c|c|c|c|c|c|c|c|}
\hline \multirow[b]{2}{*}{ Organism } & \multirow[b]{2}{*}{ Classification } & \multicolumn{3}{|c|}{ Site A } & \multicolumn{3}{|c|}{ Site B } & \multicolumn{3}{|c|}{ Site C } & \multicolumn{3}{|c|}{ Site D } \\
\hline & & $\mathrm{BE}$ & DU & $\mathrm{AF}$ & $\mathrm{BE}$ & DU & $\mathrm{AF}$ & $\mathrm{BE}$ & DU & $\mathrm{AF}$ & $\mathrm{BE}$ & DU & $\mathrm{AF}$ \\
\hline Aquatic worm & Oligochaeta $^{\mathrm{d}}$ & 6.5 & 3.4 & 0.4 & 7.3 & 6.7 & 0.3 & 13.8 & 0.7 & 0.9 & 9.6 & 1.0 & 0.1 \\
\hline Backswimmer & Notonectidae $^{b}$ & & & & & & & & & & 0.4 & & \\
\hline Caddisfly larva & Trichoptera $^{c}$ & & & 0.6 & 0.3 & 0.4 & 2.8 & 6.2 & & 5.9 & 4.0 & & 1.2 \\
\hline Crane fly larva & Tipulidae $^{b}$ & & 0.1 & & & 0.1 & & & & 0.1 & & & \\
\hline Crayfish & Astacidea $^{c}$ & 0.3 & 0.1 & & 1.0 & & 0.1 & 0.7 & 0.3 & & 0.1 & 0.1 & \\
\hline Damselfly larva & Zygoptera ${ }^{c}$ & & 0.1 & 0.1 & & 0.1 & 0.1 & & & & & 0.3 & 0.7 \\
\hline Freshwater clam & Veneroida ${ }^{c}$ & & & & & & & 3.7 & 0.3 & & 1.2 & 0.3 & \\
\hline Horsehair worm & Nematomorpha & & 0.4 & 0.6 & & 0.1 & 0.3 & & 2.5 & 5.6 & & 2.1 & 0.3 \\
\hline Leech & Hirudinea $^{d}$ & & & & & & & 0.6 & & & & & \\
\hline Lunged snail & Fisherola $^{a}$ & 0.1 & 0.1 & & 0.1 & & & 0.1 & 0.1 & 0.1 & & 0.7 & \\
\hline Mayfly larva & Ephemeroptera & 1.9 & 0.4 & 0.1 & 3.0 & 10.4 & 4.4 & 8.0 & 0.9 & 0.1 & 5.5 & 1.5 & 1.3 \\
\hline Midge & Nematocera $^{c}$ & 0.1 & 0.9 & & 3.0 & 1.2 & & 6.2 & & & 5.0 & 0.1 & \\
\hline Predaceous diving beetle & Dytiscidae ${ }^{b}$ & & 0.1 & 0.6 & & & 0.1 & 1.0 & & & 0.1 & 0.1 & 0.1 \\
\hline Planarian & Dugesiidae $^{b}$ & & & & & 0.1 & 0.1 & 0.1 & & & 0.1 & & \\
\hline Riffle beetle larva & Elmidae $e^{b}$ & & 0.1 & & 0.7 & 1.0 & 0.1 & 1.3 & 0.3 & & 0.4 & 0.4 & \\
\hline Scud & Amphipoda & 0.4 & 0.7 & 2.7 & 0.7 & 1.3 & 0.7 & 0.4 & 0.3 & & 0.1 & 0.4 & \\
\hline Soldier fly larva & Stratiomyidae $e^{b}$ & & & & & & & 0.1 & & & 0.1 & & \\
\hline Sowbug & Isopoda & & & & & 0.1 & & & & & & & \\
\hline Stonefly larva & Plecoptera $^{c}$ & & & & 0.1 & 0.6 & & 0.3 & & & 0.1 & & \\
\hline Water boatman & Corixidae $^{b}$ & & 0.1 & & & & & & & 0.1 & & & \\
\hline Water bug & Nepomorpha ${ }^{b}$ & & & & 0.1 & & & & & & & & \\
\hline Water flea & Cladocera $^{\mathrm{d}}$ & 0.1 & & & & & & 0.1 & & & & & \\
\hline Water penny beetle & Psephenidae $e^{b}$ & & & & 0.1 & 0.6 & & 0.3 & & & 0.3 & 0.1 & 0.1 \\
\hline Water snipe fly larva & Athericidae $^{b}$ & & & & & 0.7 & & & 0.3 & & & & \\
\hline
\end{tabular}

\section{${ }^{\mathrm{a} G e n u s}$}

${ }^{\mathrm{b}}$ Family

'Order (including infra-, sub-)

${ }^{\mathrm{d}}$ Class (including sub-)

ephylum

construction, and $2.8 \pm 0.8$ after construction $(\mathrm{df}=2, F=$ 46.73, $p<0.001$; Fig. 4b). This is equivalent to a $-61.6 \%$ decrease. After construction, taxon richness had become similar across the four sites $(\mathrm{df}=3, \mathrm{~F}=1.11, p=0.370)$.

Site A had a lower Shannon-Weaver species diversity compared to the other sites before construction $(\mathrm{df}=3$, $F=5.71, p=0.005$; Table 1); however, this diversity increased during construction (Fig. 4c) and became more similar across all four sites during $(\mathrm{df}=3, F=1.71$, $p=0.197)$ and after construction ( $\mathrm{df}=3, F=2.19, p=$ 0.125 ; Table 2 ). Species diversity did not change significantly with time at site $\mathrm{B}$ and site $\mathrm{D}(p>0.05)$. The species diversity trend at site $\mathrm{C}$ was opposite to that observed at site A, declining from $1.3 \pm 0.2$ before construction to $0.9 \pm 0.1$ during construction and $0.7 \pm 0.1$ after the construction ( $\mathrm{df}=2, F=5.24, p=0.020$; Fig. 4c).

\section{Discussion}

Increased turbidity during construction, improved DO after construction

The stream diversion created before the start of flow improvement work in the North Branch Park River accelerated the water flow around the site, causing increased sediment detachment and turbidity during construction. A secondary cause of increased turbidity was the materials used for construction, such as coarse sand. Even during low intensity rainfall, these materials were rapidly carried off into the stream by surface runoff generated on paved surfaces (Meyer et al. 2005). After the work was completed, rerouting the stream to its original flow path stirred up even more sediment. Although water samples were highly transparent, turbidity approached the upper limit of class $\mathrm{AA} / \mathrm{A} / \mathrm{B}$ water 

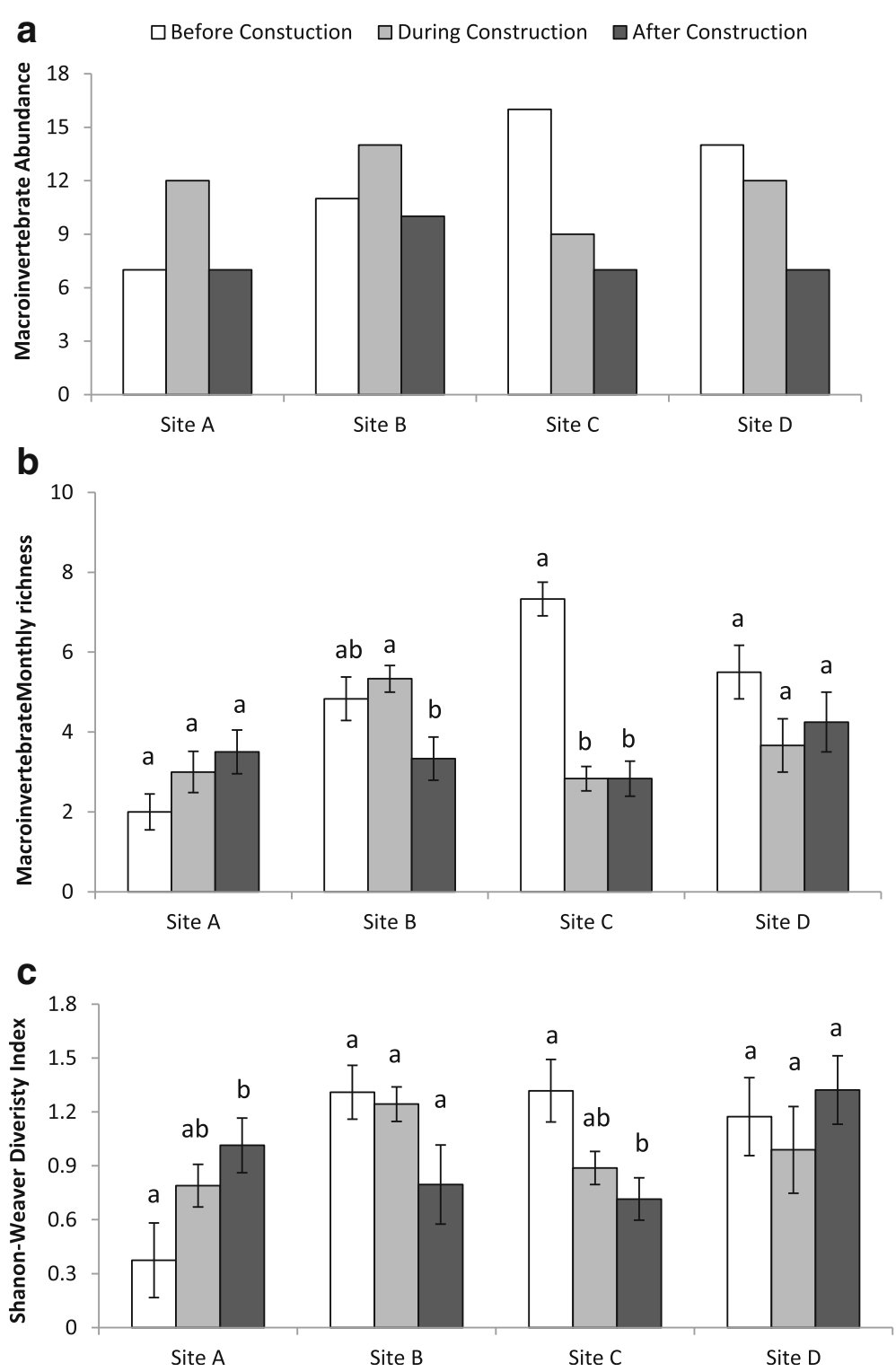

Fig. 4 Taxon abundance (a), monthly mean taxon richness (b), and Shannon-Weaver Diversity index (c) at the four study sites in the Park River. Data in panels $\mathbf{b}$ and $\mathbf{c}$ were represented as mean \pm 1 SE. The $(a, b)$ markings above the columns indicate the groups identified with the Tukey test $(a=0.05)$

quality standards in Connecticut (5 NTU over ambient levels; State of Connecticut Department of Energy and Environmental Protection 2013 regulations for Clean Water Act purposes). The increase in DO at the modified site indicates that vertical mixing, and likely also horizontal mixing, improved now after the water flow was no longer confined to culverts.

\section{Limited impact on nitrate and TP}

Changes in nitrate and TP were similar across the four sampling sites, and no evidence was found pointing to a link between nutrient concentrations and hydromodification at site C. Although not evaluated, the changes in nutrients are likely connected to changes in nitrate and TP input attributed to combined sewer overflows (Fuss and O'Neill 2010). Input variations can result from a variety of temporal patterns in precipitation, rain storm frequency, snow accumulation, and snow melt. Given the small size and urban character of the watershed, in-stream conversion of nutrients has a much smaller impact on nutrient concentrations than input variations. The lack of evidence for hydromodification impact on in-stream nutrient concentrations is in line with studies involving larger scale bridge construction projects (Purcell et al. 2012). 


\section{Decreased taxon richness and species diversity}

Increased turbidity was accompanied by a decline of taxon richness and species diversity at the construction site, but not further downstream. The $61.8 \%$ decline in taxon richness immediately downstream of the construction site (site C) was substantial, and the benthic macroinvertebrates that are sensitive to minor changes in water quality disappeared altogether (Covich et al. 1999). Nonetheless, construction did not appear to affect taxon richness and diversity further downstream (at site D), while taxon abundance recovered within the year. The local baseline of taxon richness and species diversity is, however, dependent on local environmental factors. The greater taxon richness and species diversity for sites downstream of the construction site vs. upstream sites has no link to hydromodification, but is explained by the type of streambed material. Benthic macroinvertebrates prefer habitats with fine sediments, including sand, to rocky streambeds (Quinn and Hickey 1990). Site C and site $\mathrm{D}$ downstream of the construction site have sandy streambed material and therefore generally greater taxon richness and species diversity compared to upstream site A and site B that have rock and gravel stream beds, respectively.

Likewise, the regression in water quality ascribed to the flow improvement work was local and short-lasted. Increased turbidity and decreased taxon richness and species diversity was most significant at site $\mathrm{C}$, limiting the negative impacts of this small-scale construction project to a distance of less than $50 \mathrm{~m}$ downstream of the site where work was conducted. The effects further downstream showed signs of recovery within the timespan of 1 year; however, the increase in local flow velocity under the bridge is permanent. Therefore, this location may not recover to pre-construction taxon richness and species diversity but instead reach a dynamic equilibrium corresponding with levels observed at upstream sites.

\section{Conclusions}

Flow improvement work was carried out in the urban North Branch Park River, where a stream crossing in the form of an embankment with eight culverts was replaced with a bridge (25-m span). This small-scale hydromodification affected the water quality as follows:

(1) Turbidity increased by $60.9 \%$ within $50 \mathrm{~m}$ downstream of the construction site and returned to the preconstruction level after the work was completed. During construction, turbidity approached the maximum level for clean water of 5 NTU over ambient levels (State of Connecticut Department of Energy and Environmental Protection 2013 regulations for Clean Water Act purposes). Dissolved oxygen increased locally during the last stage of our survey, indicating that hydromodification resulted in better vertical mixing.

(2) There was no evidence that hydromodification affected nitrate and TP concentrations in stream water. Respective changes were similar at upstream and downstream sites and therefore most likely caused by variations in nutrient input associated with combined sewer overflows.

(3) Benthic macroinvertebrate taxon richness and species diversity declined by 61.6 and $32.6 \%$, respectively, during construction. This negative effect on the aquatic ecosystem was limited to within $50 \mathrm{~m}$ downstream of construction. But neither taxon richness nor species diversity recovered within 1 year after flow improvement was completed. Nonetheless, benthic macroinvertebrate communities may yet recover given that turbidity subsided and DO increased in the year following construction.

Urban aquatic ecosystem and water quality-related services are very sensitive to the impacts of small-scale hydromodification projects, and our results underline the importance of environmental assessments prior to modification of flow structures.

\section{Acknowledgements \\ We thank Germaine Clarke, Kelly Fancher, Amber Gipson, and Olivia Leach who helped with sample collection and analysis. We deeply appreciate the comments from Dr. Jiquan Chen and the three anonymous reviewers. This contribution was edited by Dr. Dennis W. Hallema, Assoc. Ed.}

\section{Funding}

Funding was provided by the Dean's Research Fund of the University of Hartford College of Arts and Sciences, and the University of Hartford Women's Advancement Initiative Fund.

Availability of data and materials

Data collected and analyzed in this study are available from the author upon request.

Authors' contributions

All authors helped review and revise the manuscript. BZ was the project leader. BZ, DSS, and APB designed the study, conducted the data analysis, and wrote the manuscript. DSS, APB, DMR, BMK, MLY, and ASP collected and processed the data. NRB created the maps and provided project guidance and expertise. All authors have read and approved the final manuscript.

Ethics approval and consent to participate

Not applicable.

Consent for publication

Not applicable.

Competing interests

The authors declare that they have no competing interests.

\section{Publisher's Note}

Springer Nature remains neutral with regard to jurisdictional claims in published maps and institutional affiliations. 


\section{Author details}

'Department of Biology, University of Hartford, 200 Bloomfield Avenue, West Hartford, CT 06117, USA. ${ }^{2}$ College of Marine and Environmental Sciences, James Cook University, 1 James Cook Drive, Townsville, QLD 4811, Australia. ${ }^{3}$ Department of Geography and Environmental Planning, Towson University, 8000 York Road, Towson, MD 21252, USA.

Received: 26 September 2017 Accepted: 14 February 2018

Published online: 12 March 2018

\section{References}

Bennett EM, Carpenter SR, Caraco NF (2001) Human impact on erodable phosphorus and eutrophication: a global perspective: increasing accumulation of phosphorus in soil threatens rivers, lakes, and coastal oceans with eutrophication. Bioscience 51(3):227-234. https://doi.org/10.1641/00063568(2001)051[0227:HIOEPA]2.0.CO;2

Berger E, Haase P, Kuemmerlen M, Leps M, Schäfer RB, Sundermann A (2017) Water quality variables and pollution sources shaping stream macroinvertebrate communities. Sci Total Environ 587:1-10. https://doi.org/ 10.1016/j.scitotenv.2017.02.031

Bilotta GS, Brazier RE (2008) Understanding the influence of suspended solids on water quality and aquatic biota. Water Res 42(12):2849-2861. https://doi.org/ 10.1016/j.watres.2008.03.018

Brabec E, Schulte S, Richard PL (2002) Impervious surfaces and water quality: a review of current literature and its implications for watershed planning. J Plan Lit 16(4):499-514

Chen Y, Viadero RC, Wei X, Fortney R, Hedrick LB, Welsh SA, Anderson JT, Lin L-S (2009) Effects of highway construction on stream water quality and macroinvertebrate condition in a mid-Atlantic highlands watershed, USA. J Environ Qual 38(4):1672-1682. https://doi.org/10.2134/jeq2008.0423

Correll DL (1998) The role of phosphorus in the eutrophication of receiving waters: a review. J Environ Qual 27(2):261-266. https://doi.org/10.2134/ jeq1998.00472425002700020004x

Covich AP, Palmer MA, Crowl TA (1999) The role of benthic invertebrate species in freshwater ecosystems: zoobenthic species influence energy flows and nutrient cycling. Bioscience 49(2):119-127. https://doi.org/10.2307/1313537

DaSilva A, Xu YJ, Beebe J, Ice GG (2013) Effects of timber harvesting on dissolved oxygen in a Northern Louisiana headwater stream. For Sci 59(2):127-138. https://doi.org/10.5849/forsci.11-038

Eaton AD, Franson MAH (2005) Standard Methods for the Examination of Water \& Wastewater. 21st edition. American Public Health Association, Washington, DC, p 1200.

Fuss and O'Neill (2010) Baseline watershed assessment North Branch Park River watershed. Connecticut Department of Environmental Protection, p 297. http://www.ct.gov/deep/lib/deep/water/watershed_management/wm_plans/ nbparkr/baseline_assess.pdf

Hassan ZU, Shah JA, Kanth TA, Pandit AK (2015) Influence of land use/land cover on the water chemistry of Wular Lake in Kashmir Himalaya (India). Ecol Process 4:9. https://doi.org/10.1186/s13717-015-0035-z

Hobbie SE, Finlay JC, Janke BD, Nidzgorski DA, Millet DB, Baker LA (2017) Contrasting nitrogen and phosphorus budgets in urban watersheds and implications for managing urban water pollution. Proc Natl Acad Sci: 201618536. https://doi.org/10.1073/pnas.1618536114

Houser DL, Pruess H (2009) The effects of construction on water quality: a case study of the culverting of Abram Creek. Environment Monitoring and Assessment 155:431-442. https://doi.org/10.1007/s10661-008-0445-9

Kuehl RO (2000) Design of experiments: statistical principles of research design and analysis, 2nd edn. Duxbury Press, Pacific Grove, California

Le C, Zha Y, Li Y, Sun D, Lu H, Yin B (2010) Eutrophication of lake waters in China: cost, causes, and control. Environ Manag 45:662-668. https://doi.org/10.1007/ s00267-010-9440-3

Lemly AD (1982) Modification of benthic insect communities in polluted streams: combined effects of sedimentation and nutrient enrichment. Hydrobiologia 87(3):229-245. https://doi.org/10.1007/BF00007232

Meyer JL, Paul MJ, Taubee WK (2005) Stream ecosystem function in urbanizing landscapes. J N Am Benthol Soc 24(3):602-612

Mundahl ND, Hunt AM (2011) Recovery of stream invertebrates after catastrophic flooding in southeastern Minnesota, USA. J Freshw Ecol 26(4):445-457. https://doi.org/10.1080/02705060.2011.596657
Patil A, Deng Z (2012) Temporal scale effect of loading data on instream nitratenitrogen load computation. Water Sci Technol 66(1):36-44. https://doi.org/10. 2166/wst.2012.163

Purcell P, Bruen M, O'Sullivan J, Cocchiglia L, Kelly-Quinn M (2012) Water quality monitoring during the construction of the M3 motorway in Ireland. Water and Environment Journal 26(2):175-183. https://doi.org/10.1111/j.1747-6593. 2011.00274.x

Quinn JM, Cooper AB, Davies-Colley RJ, Rutherford JC, Williamson RB (1997) Land use effects on habitat, water quality, periphyton, and benthic invertebrates in Waikato, New Zealand, hill-country streams. N Z J Mar Freshw Res 31(5):579-597. https://doi.org/10.1080/00288330.1997.9516791

Quinn JM, Hickey CW (1990) Magnitude of effects of substrate particle size, recent flooding, and catchment development on benthic invertebrates in 88 New Zealand rivers. N Z J Mar Freshw Res 24(3):411-427. https://doi.org/10. 1080/00288330.1990.9516433

State of Connecticut Department of Energy and Environmental Protection (2013). Connecticut Water Quality Standards (Effective December 11, 2013). State regulation establishing water quality standards for surface and ground waters of the state in effect for Clean Water Act purposes. URL: https://www. epa.gov/wqs-tech/water-quality-standards-regulations-connecticut

Sun G, Hallema DW, Asbjornsen H (2017) Ecohydrological processes and ecosystem services in the Anthropocene: a review. Ecol Process 6(1):35. https://doi.org/10.1186/s13717-017-0104-6

Thorp JH, Covich AP (2009) Ecology and classification of North American freshwater invertebrates. $3^{\text {rd }}$ Edition. Academic Press, London. p 1028

Weigel BM, Henne LJ, Martinez-Rivera LM (2002) Macroinvertebrate-based index of biotic integrity for protection of streams in west-central Mexico. J N Am Benthol Soc 21(4):686-700. https://doi.org/10.2307/1468439

Wilson MA, Carpenter SR (1999) Economic valuation of freshwater ecosystem services in the United States: 1971-1997. Ecol Appl 9(3):772-783. https://doi. org/10.1890/1051-0761(1999)009[0772:EVOFES]2.0.CO;2

Zhu B, Fitzgerald DG, Mayer CM, Rudstam LG, Mills EL (2006) Alteration of ecosystem function by zebra mussels in Oneida Lake: impacts on submerged macrophytes. Ecosystems 9(6):1017-1028. https://doi.org/10.1007/s10021 005-0049-y

Zhu B, Kopco J, Rudstam LG (2015) Effects of invasive European frogbit and its two physical control methods on macroinvertebrates. Freshwater Science 34(2):497-507. https://doi.org/10.1086/680987

\section{Submit your manuscript to a SpringerOpen ${ }^{\circ}$ journal and benefit from:}

- Convenient online submission

- Rigorous peer review

- Open access: articles freely available online

- High visibility within the field

Retaining the copyright to your article

Submit your next manuscript at $>$ springeropen.com 